\title{
Impact of applied silvicultural systems on spatial pattern of hornbeam-oak forests
}

\author{
Zdeněk Vacek ${ }^{1 *}$, Stanislav Vacek ${ }^{1}$, Lukáš Bílek ${ }^{1}$, Jan Král ${ }^{1}$, \\ Iva Ulbrichová ${ }^{1}$, Jaroslav Simon ${ }^{2}$, Daniel Bulušek ${ }^{1}$ \\ ${ }^{1}$ Czech University of Life Sciences Prague, Faculty of Forestry and Wood Sciences, Kamýcká 129, \\ CZ - 16521 Prague 6 - Suchdol, Czech Republic \\ ${ }^{2}$ Mendel University in Brno, Department of Forest Management and Applied Geoinformatics, Zemědělská 3 , \\ CZ-613 00 Brno, Czech Republic
}

\begin{abstract}
The spatial pattern of forest closely affects tree competition that drives the most of processes in forest ecosystems. Therefore, we focused on evaluation of the horizontal structure of high forest, coppice with standards and low forest in hornbeam-oak forests in the Protected Landscape Area Český kras (Czech Republic). The horizontal structure of tree layer individuals with crown projection centroids and natural regeneration was analysed for durmast oak (Quercus petraea (Matt.) Liebl.), European hornbeam (Carpinus betulus L.) and small-leaved linden (Tilia cordata Mill.) stands. Horizontal structure of the tree stems of the studied tree species in high forest was random, in oak it was moderately regular. In coppice with standards it was random in oak, in hornbeam and linden it was aggregated within $3-5 \mathrm{~m}$ and random up to a larger spacing. In low forest at a distance of $4-6 \mathrm{~m}$ the horizontal structure of the three studied tree species was aggregated while it was random at a larger spacing. The horizontal structure of natural regeneration was aggregated in all forest types. In coppice with standards and high forest, parent stand had significant negative effect on the natural regeneration at smaller distance (to $1.4 \mathrm{~m}$ from the stem). Crown centroids were more regularly distributed than tree stems, especially in low forest $(2.0 \mathrm{~m})$ and in linden $(2.3 \mathrm{~m})$. Our results contribute to existing knowledge about silvicultural systems and their impact on hornbeam-oak forests with implications for forest management and nature protection.
\end{abstract}

Key words: forest management; horizontal structure; forest dynamics; natural regeneration; Czech Republic

Editor: Bohdan Konôpka

\section{Introduction}

Analyses of the spatial distribution of trees in forest stands, either horizontal (regular, random and aggregated) or vertical (especially coenotic position), improve our knowledge of dynamic processes on the stand level (Pretzsch 2009; Vacek et al. 2015a). Spatial structure expresses the tree distribution within a space and at the same time it reflects local living conditions in the environs of any tree while these microsite conditions influence the dynamic natural processes such as growth, mortality and regeneration of forest stands and particular trees (Courbaud et al. 2001; Petritan et al 2007; Bulušek et al. 2016; Cukor et al. 2017).

Numerous methods of the spatial structure analysis were described in many studies of the forest ecosystem ecology (Goreaud 2000; Pommerening 2002; Goreaud \&
Pélissier 2003; Perry et al. 2006; Pommerening \& Stoyan 2006; Vacek et al. 2014). The majority of the studies are aimed at the position of the stem base. These studies compare forest stands and their stand types on the basis of the analysis of particular tree species, tree classes, diameter at breast height or height with respect to their spatial structure (Song et al. 2004) or they examine changes in the spatio-temporal structure in relation to silvicultural practices or natural processes such as growth, regeneration and mortality (Vacek \& Lepš 1996; Ward et al. 1996; Goreaud 2000; Moser et al. 2002; Montes et al. 2004).

The interactions of the overstorey and understorey structure were described by Paillet et al. (2010), who confirmed that a change in the overstorey characteristics, mainly due to management in forests, has a great influence on the species richness of several taxonomic groups. Nevertheless, the reaction of plant species on spatial 
pattern in understorey is usually different (Bulušek et al. 2016; Slanař et al. 2017). For this reason, of crucial importance for sustainability is to understand the effect of a change in forest structure through forest management practices on understorey (Burrascano et al. 2011).

Coppice forest is one of the oldest forest systems known from many countries all around the world (Fujimori 2001). Coppices were used as a wood source until the second half of the $19^{\text {th }}$ century (Peterken 1993). Since then, coppices have practically disappeared (Kopecký et al. 2013) because of gradual conversion of low forests to high forests, especially in central and northwestern Europe (Matthews 1991; Peterken 1993). The main reason for forest conversion was increasing demand for timber of higher quality (Hédl et al. 2010) and policy of nature conservation that considered the low forest system as undesirable at that time (Szabó 2010). On the contrary, the abandonment of this system can cause a reduction in species diversity (Spitzer et al. 2008) because of structure homogenization that limits mainly light-demanding species (Kopecký et al. 2013). Such a trend was proved by Vanhellemont et al. (2014), who demonstrated a decrease in the representation of light-demanding species and an increase in maple (Acer platanoides L.) and hazel (Corylus avellana L.).

Nowadays we see an increasing interest for coppicing (Mason \& MacDonald 2002; Müllerová et al. 2015), which has three main reasons: i) increasing demand for firewood (Šplíchalová et al. 2012), ii) increasing interest in nature protection, biodiversity and landscaping (Fuller 1992; Gurnell et al. 1992; Spitzer et al. 2008; Kopecký et al. 2013), iii) small forest owners consider this form of forest management as more suitable for their properties. Even though the interest in coppicing has increased, there is still a lack of information on the influence of silvicultural systems of forests on their ecological characteristics, properties of tree species growth and their structure
(Fürst et al. 2007; Vacík et al. 2009; Matula et al. 2012). Very little knowledge is available especially of the horizontal distribution of tree stems and crowns in stands of different silvicultural systems, i.e. in low forest, coppice with standards and in high forest (Sumida et al. 2002; Pretzsch \& Schütze 2005). In general, it is to state that aggregated spatial distribution of trees, which is a result of several stems that have developed from one stump, are usually typical of low forest, unlike high forests (Jancke et al. 2009).

The objective of this study was to evaluate the influence of silvicultural system and management on the spatial pattern of hornbeam-oak forests and its development in National Nature Reserve (NNR) Karlštejn in the last 12years (2002-2014). The particular aims were to determine the horizontal, diameter and height structure of tree layer and regeneration individuals across the main tree species [durmast oak (Quercus petraea (Matt.) Liebl.), European hornbeam (Carpinus betulus L.) and smallleaved linden (Tilia cordata Mill.)] and analyse the crown plasticity of trees. We tested a hypothesis that aggregated distribution of individuals in the tree layer is typical of low forest and that in coppice with standards and in high forest with increasing number of generative individuals the distribution changes towards random or regular. When comparing tree stem bases and tree crowns, we expect more regular distribution in the latter case.

\section{Material and methods}

\subsection{Study area}

Study site is situated in the NNR Karlštejn in the Protected Landscape Area (PLA) Český kras in middle Bohemia (Fig. 1). The study was conducted on 3 permanent research plots (PRP) in the Doutnáč forest complex

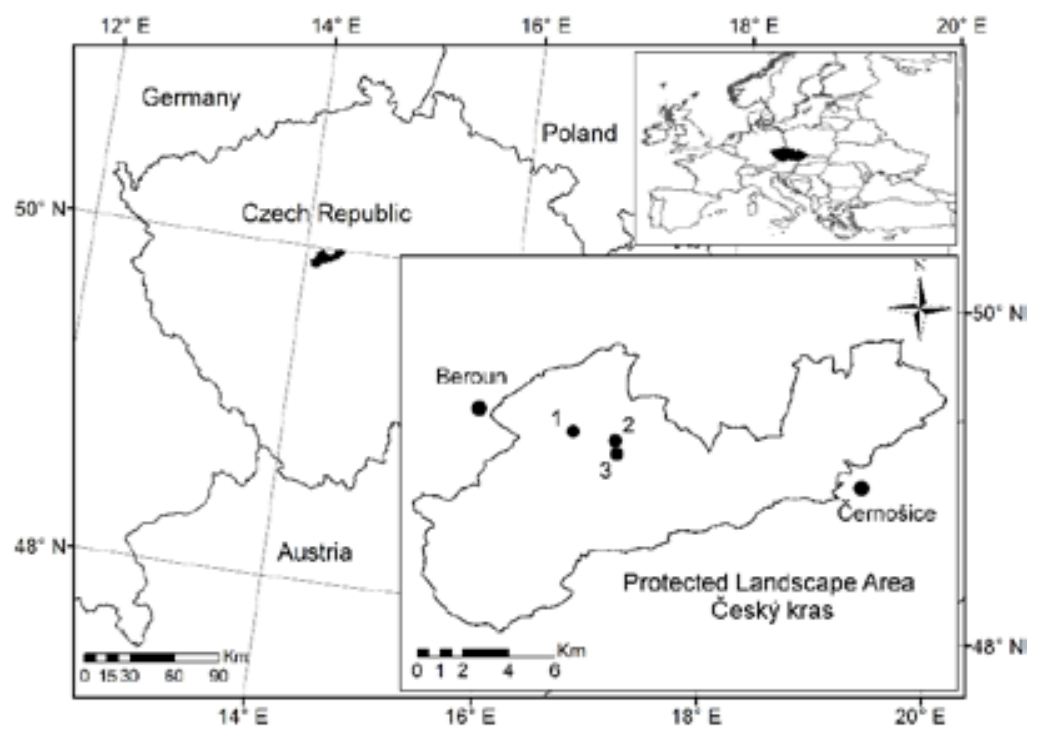

Fig. 1. Localization of hornbeam-oak forests on permanent research plots $1-3$ in the locality Doutnáč, Protected Landscape Area Český kras. 
Table 1. Basic site and stands characteristics of permanent research plots.

\begin{tabular}{|c|c|c|c|c|c|c|c|c|c|c|c|}
\hline PRP & Tree species & Age & $\begin{array}{l}\text { Height } \\
{[\mathrm{m}]}\end{array}$ & $\begin{array}{l}\text { DBH } \\
{[\mathrm{cm}]}\end{array}$ & $\begin{array}{c}\text { Stand volume } \\
{\left[\mathrm{m}^{3} \mathrm{ha}^{-1}\right]}\end{array}$ & $\begin{array}{c}\text { Altitude } \\
{[\mathrm{m}]}\end{array}$ & Exposure & $\begin{array}{c}\text { Slope } \\
{\left[{ }^{\circ}\right]}\end{array}$ & Forest site type & Soil type & Forest form \\
\hline \multirow{7}{*}{1} & Oak & & 17 & 19 & 68 & \multirow{7}{*}{405} & \multirow{7}{*}{ NW } & \multirow{7}{*}{6} & \multirow{7}{*}{$2 \mathrm{~W}$} & \multirow{7}{*}{$\begin{array}{c}\text { Rendzina } \\
\text { modal }\end{array}$} & \multirow{7}{*}{ High forest } \\
\hline & Beech & & 22 & 23 & 50 & & & & & & \\
\hline & Linden & & 19 & 20 & 34 & & & & & & \\
\hline & Hornbeam & 83 & 16 & 17 & 18 & & & & & & \\
\hline & Ash & & 22 & 24 & 12 & & & & & & \\
\hline & Wild service tree & & 18 & 22 & 5 & & & & & & \\
\hline & Maple & & 18 & 19 & 3 & & & & & & \\
\hline \multirow{8}{*}{2} & Oak & & 17 & 22 & 58 & \multirow{8}{*}{433} & \multirow{8}{*}{$\mathrm{NE}$} & \multirow{8}{*}{2} & \multirow{8}{*}{$\begin{array}{c}2 \mathrm{~A} \\
(2 \mathrm{~W})\end{array}$} & \multirow{8}{*}{$\begin{array}{c}\text { Rendzina } \\
\text { modal }\end{array}$} & \multirow{8}{*}{$\begin{array}{l}\text { Copicce with } \\
\text { standards }\end{array}$} \\
\hline & Linden & & 17 & 21 & 57 & & & & & & \\
\hline & Hornbeam & & 15 & 16 & 18 & & & & & & \\
\hline & Beech & 107 & 20 & 24 & 22 & & & & & & \\
\hline & Larch & 101 & 21 & 29 & 15 & & & & & & \\
\hline & Ash & & 18 & 18 & 8 & & & & & & \\
\hline & Birch & & 19 & 23 & 2 & & & & & & \\
\hline & Aspen & & 23 & 27 & 3 & & & & & & \\
\hline \multirow{5}{*}{3} & Linden & & 18 & 19 & 58 & \multirow{5}{*}{415} & \multirow{5}{*}{ SE } & \multirow{5}{*}{17} & \multirow{5}{*}{$2 \mathrm{~W}$} & \multirow{5}{*}{$\begin{array}{c}\text { Rendzina } \\
\text { melanic }\end{array}$} & \multirow{5}{*}{ Low forest } \\
\hline & Hornbeam & & 16 & 15 & 42 & & & & & & \\
\hline & Oak & 86 & 17 & 19 & 37 & & & & & & \\
\hline & Maple & & 18 & 18 & 5 & & & & & & \\
\hline & Ash & & 18 & 18 & 3 & & & & & & \\
\hline
\end{tabular}

Note: oak - Quercus petraea (Matt.) Liebl., linden - Tilia cordata Mill., hornbeam - Carpinus betulus L., beech - Fagus sylvatica L., larch - Larix decidua Mill., ash - Fraxinus excelsior L., birch - Betula pendula Roth, aspen - Populus tremula L., wild service tree - Sorbus torminalis (L.) Crantz, maple - Acer platanoides L.; 2A - Stony-colluvial maple-beech-oak forest, 2W - Limestone beech-oak forest.

of 67.64 ha in size (Table 1). Approximately until the mid-20 ${ }^{\text {th }}$ century the forests of Karlštejn locality were managed as coppices with standards with a low share of the overstorey of standards and high intensity of felling in coppice forest and cattle grazing. After the NNR Karlštejn was declared in 1955, forest management activities were completely terminated in 2004.

Annual average temperature ranged between $8-9^{\circ} \mathrm{C}$ and precipitation is around $560 \mathrm{~mm}$ (Tolasz et al. 2007). A territory of the study site is characterized by warm dry summer and cool dry winter with a narrow annual temperature range (group Cfb, Köppen 1936), where average length of the growing season is about 165 days. The geological bedrock is mainly composed of grey or red limestones. Prevailing soils are Rendzinas, Luvisols and Cambisols (Němeček et al. 2001). According to forest site type classification study area of hornbeam-oak forestsand scree forests belongs to Fageto-Quercetum calcarium.

\subsection{Data collection}

A theodolite was used for stem mapping within PRP 1 - 3 of $100 \times 50 \mathrm{~m}(0.50 \mathrm{ha})$ in 2002 . A FieldMap technology (IFER) was applied for a repeated measurement on PRP in 2014. During both measurements the position of all tree layer individuals of breast height diameter (DBH) $\geq 4 \mathrm{~cm}$ was localized. In the tree layer heights of the live crown base and crown perimeter were measured, minimally at 4 directions perpendicular to each other. $\mathrm{DBH}$ of the tree layer were measured with a metal calliper to the nearest $\mathrm{mm}$ while tree heights and heights of the live crown base were recorded with a laser Vertex hypsometer to the nearest $0.1 \mathrm{~m}$.
Natural regeneration was mapped in 2014 on $10 \times$ 50 transects on each PRP that were representative from the aspect of regeneration. For seedlings (measured all individuals 1 year and older) and saplings following characteristics were measured: position, height, height of the live crown base and crown width to the nearest $\mathrm{cm}$.

\subsection{Data analysis}

For tree stems, crown centroids and natural regeneration, horizontal structure on particular plots was evaluated by Ripley's $L$-function (Ripley 1981) for all individuals and separately for the main tree species (durmast oak, European hornbeam and small-leaved linden). A test of the significance of deviations from the values expected for the random distribution of points was done by means of Monte Carlo simulations. The mean values of $L$-function were estimated as arithmetic means from $L$-functions computed for 1999 randomly generated point structures. Following stand structural indices based on a different type of calculation were computed: Hopkins-Skellam index (Hopkins \& Skellam 1954), Pielou-Mountford index (Pielou 1959; Mountford 1961) and Clark-Evans index (Clark \& Evans 1954). Among distribution indices based on the tree frequency in the particular quadrats David-Moore index (David \& Moore 1954) was used. The quadrat size on PRP was $10 \times 10 \mathrm{~m}$ (25 quadrats) and transects were divided into 80 quadrats $(2.5 \times 2.5 \mathrm{~m}$ each). The calculation of these characteristics was made using PointPro 2.1 software (Zahradník). Tab. 2 gives basic criteria of these indices. The relationship between spatial pattern of tree layer and natural regeneration were calculated by software R 3.1. (The R Foundation) by pair cross correlation function (Stoyan \& Stoyan 1992). 
Table 2. Overview of the indices describing the horizontal structure and their common interpretation.

\begin{tabular}{|c|c|c|c|c|}
\hline Index & Reference & Mean value & Aggregation & Regularity \\
\hline Index of non-randomness A & Hopkins \& Skellam 1954 & $\mathrm{~A}=0.5$ & $\mathrm{~A}>0.5$ & $\mathrm{~A}<0.5$ \\
\hline Index of non-randomness $\alpha$ & Pielou 1959; Mountford 1961 & $\alpha=1$ & $\alpha>1$ & $\alpha<1$ \\
\hline Index of aggregation $\mathrm{R}$ & Clark \& Evans 1954 & $\mathrm{R}=1$ & $\mathrm{R}<1$ & $\mathrm{R}>1$ \\
\hline Index of cluster size ICS & David \& Moore 1954 & $\mathrm{ICS}=0$ & $\mathrm{ICS}>0$ & ICS $<0$ \\
\hline
\end{tabular}

Statistical analyses were processed in the Statistica 12 software (StatSoft). The differences between tree crown plasticity of PRP and tree species were tested by one-way analysis of variance (ANOVA) and consequently tested by post-hoc comparison Tukey's HSD tests. In order to examine the interactions among stand characteristics and indices of horizontal structure, unconstrained principal component analysis (PCA) in Canoco 5.03 programme (Microcomputer Power) was applied. Data were centred and standardized before the analysis. The results of the PCA were visualized in the form of an ordination diagram.

\section{Results}

\subsection{Tree layer}

The diameter distribution clearly shows difference between the particular types of forest (Fig. 2). In the high forest (PRP 1), the lowest number of trees belongs to small diameter classes while this number is obviously the highest in low forest (PRP 3), and in coppice with standards (PRP 2) the values are rather closer to low forest even with higher variability. Left-sided shape of diameter classes with high density of trees is characterized for low forest. Contrary, low number of trees with gauss curve shape of diameter classes is typical for even aged high forest (Fig. 2).

The spatial pattern of tree layer of the low forest situated on PRP 3 was aggregated according to $A, \alpha$, and $R$ indices while it was random according to ICS index (Table 3 ). The $L$-function show that the highest intensity of aggregation occurred at tree distance of 0 to $3 \mathrm{~m}$ (Fig. 3). The tree layer of coppice with standards on PRP 2 was distributed randomly as shown identically by all computed structural indices (Tab. 3 ) and $L$-function (Fig. 3) with tendency to aggregation in 2014. The spatial pattern of trees of a high forest situated on PRP 1 was moderately regular according to ICS indices, while it was random according to A, $\alpha$ and R index (Fig. 3, Table 3). The regular and random pattern of the trees according to their distances was also indicated by the $L$-function (Fig. 3). In course of 12 years, the highest dynamics of horizontal structure was observed in coppice with standard and low forest, while high forest showed minimum changes in spatial pattern.
PRP 1

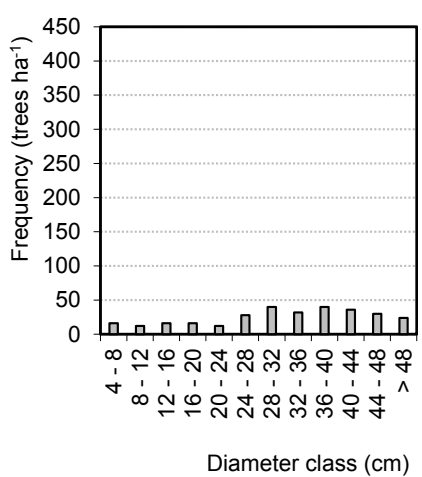

PRP 2

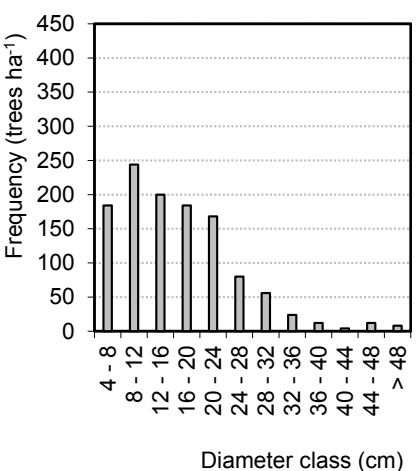

PRP 3

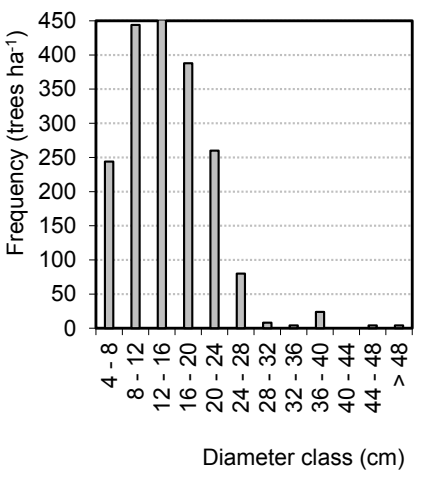

Fig. 2. Diameter structure of tree layer on permanent research plots 1 (high forest), 2 (coppice with standards) and 3 (low forest).

Table 3. Structural indices of stem bases for the main tree species and all tree individuals on permanent research plot 1 (high forest), 2 (coppice with standards) and 3 (low forest) in 2002 and 2014.

\begin{tabular}{|c|c|c|c|c|c|c|c|c|c|c|c|c|c|}
\hline \multirow{2}{*}{ Index } & \multirow{2}{*}{ Year } & \multicolumn{4}{|c|}{ PRP 1 } & \multicolumn{4}{|c|}{ PRP 2 } & \multicolumn{4}{|c|}{ PRP 3 } \\
\hline & & oak & hornbeam & linden & tree layer & oak & hornbeam & linden & tree layer & oak & hornbeam & linden & tree layer \\
\hline \multirow{2}{*}{ A } & 2002 & 0.41 & 0.42 & 0.62 & 0.43 & 0.52 & $0.66^{\mathrm{A}}$ & $0.67^{\mathrm{A}}$ & 0.53 & $0.71^{\mathrm{A}}$ & $0.79^{\mathrm{A}}$ & $0.92^{\mathrm{A}}$ & $0.69^{\mathrm{A}}$ \\
\hline & 2014 & 0.45 & 0.44 & 0.62 & 0.43 & 0.54 & $0.67^{\mathrm{A}}$ & $0.67^{\mathrm{A}}$ & $0.56^{\mathrm{A}}$ & $0.73^{\mathrm{A}}$ & $0.83^{\mathrm{A}}$ & $0.93^{\mathrm{A}}$ & $0.67^{\mathrm{A}}$ \\
\hline \multirow[b]{2}{*}{$\alpha$} & 2002 & 0.90 & 0.98 & 1.75 & 0.92 & 1.16 & 1.37 & 1.54 & 1.15 & $1.68^{\mathrm{A}}$ & $1.87^{\mathrm{A}}$ & $2.81^{\mathrm{A}}$ & $1.44^{\mathrm{A}}$ \\
\hline & 2014 & 0.99 & 1.06 & 1.76 & 0.95 & 1.25 & 1.30 & $2.07^{\mathrm{A}}$ & 1.17 & $1.86^{\mathrm{A}}$ & $2.08^{\mathrm{A}}$ & $2.93^{\mathrm{A}}$ & $1.39^{\mathrm{A}}$ \\
\hline \multirow{2}{*}{$\mathrm{R}$} & 2002 & 1.13 & 1.16 & 1.03 & 1.10 & 1.03 & $0.72^{\mathrm{A}}$ & $0.63^{\mathrm{A}}$ & 0.97 & $0.69^{A}$ & $0.49^{\mathrm{A}}$ & $0.32^{\mathrm{A}}$ & $0.71^{\mathrm{A}}$ \\
\hline & 2014 & 1.10 & 1.16 & 1.03 & 1.10 & 1.03 & $0.67^{\mathrm{A}}$ & $0.42^{\mathrm{A}}$ & $0.89^{\mathrm{A}}$ & $0.69^{A}$ & $0.47^{\mathrm{A}}$ & $0.32^{\mathrm{A}}$ & $0.72^{\mathrm{A}}$ \\
\hline \multirow{2}{*}{ ICS } & 2002 & -0.30 & -0.27 & 0.01 & $-0.29^{R}$ & -0.07 & 0.24 & 0.84 & 0.15 & $0.53^{\mathrm{A}}$ & $1.21^{\mathrm{A}}$ & $2.73^{\mathrm{A}}$ & 0.25 \\
\hline & 2014 & -0.31 & -0.23 & 0.01 & $-0.27^{\mathrm{R}}$ & -0.07 & 0.25 & $1.81^{\mathrm{A}}$ & $0.45^{\mathrm{A}}$ & 0.64 & $1.10^{\mathrm{A}}$ & $2.68^{\mathrm{A}}$ & 0.21 \\
\hline
\end{tabular}

Notes: $^{\text {A, }}$ statistically significant $(\alpha=0.05 ; \mathrm{A}$ - aggregation, $\mathrm{R}$ - regularity). 
PRP 1

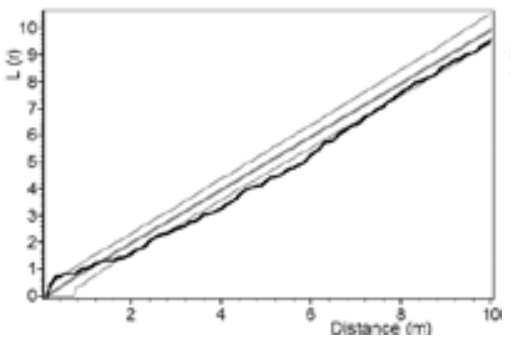

PRP 2

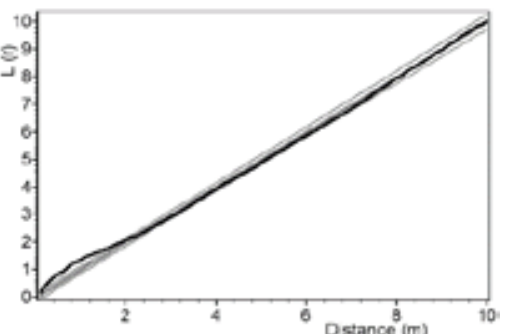

PRP 3

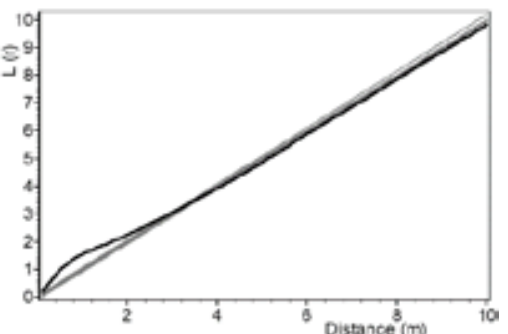

Fig. 3. Horizontal structure of tree layer on permanent research plots 1 (high forest), 2 (coppice with standards) and 3 (low forest) expressed by $L$-function; the bold grey line represents the mean course for random spatial distribution of trees and the two thinner central curves represent $95 \%$ interval of reliability; when the black line of tree distribution on plot is below this interval, it indicates a tendency of trees toward regular distribution, and if it is above this interval, it shows a tendency toward aggregation.

Horizontal structure of stem bases in the tree layer of the studied tree species (durmast oak, European hornbeam, small-leaved linden) in high forest on PRP 1 in oak was moderately regular at a spacing of 3-6 m (Fig. 4). The horizontal structure in hornbeam and linden was aggregated to a distance of 5.5 and $6 \mathrm{~m}$, and farther it was also random. Horizontal structure in coppice with standards on PRP 2 was random in oak, aggregated in hornbeam and linden to a distance of $3-5 \mathrm{~m}$ and random at a larger spacing and tended toward random distribution in the course of dynamics. In low forest on PRP 3 in oak the horizontal structure of trees at a distance within $4 \mathrm{~m}$ was distinctly aggregated and indistinctly aggregated at a spacing of $4-8 \mathrm{~m}$, and at a larger spacing it was random (Fig. 6). Only changes in horizontal structure occurred in the course of the studied 12 years.

The same information about horizontal structure of stem bases of the main tree species in the tree layer was provided by structural indices (Table 3). In high forest on PRP 1 the majority of the indices show regular tree distribution for most tree species across the forest stand. Only in linden the distribution was aggregated according to $\alpha$ and ICS indices while the $A$ index shows this type of distribution in linden only. In coppice with standards on PRP 2 the majority of the indices suggest the aggregated distribution of trees for most woody species, and $R$ and $I C S$ indices indicate regular distribution in oak only. In low forest on PRP 3 the trees of all tree species were distributed in a significant aggregated pattern according to all indices.

\subsection{Tree crown plasticity}

A comparison of the indices of the centroids of horizontal crown projection areas with the centroids of stem base
PRP 1 tree stem oak

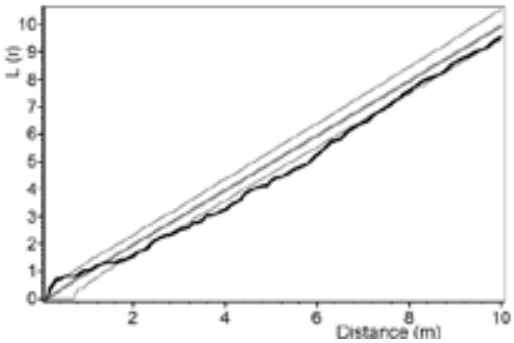

PRP 1 crown oak

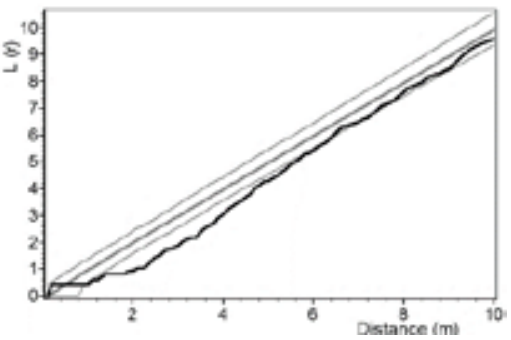

PRP 1 tree stem hornbeam

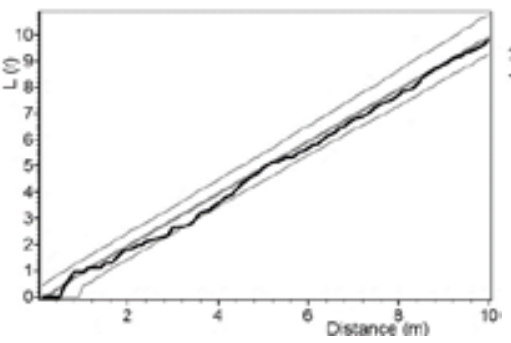

PRP 1 crown hornbeam

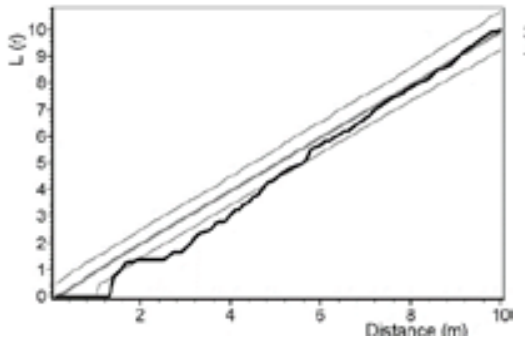

PRP 1 tree stem linden

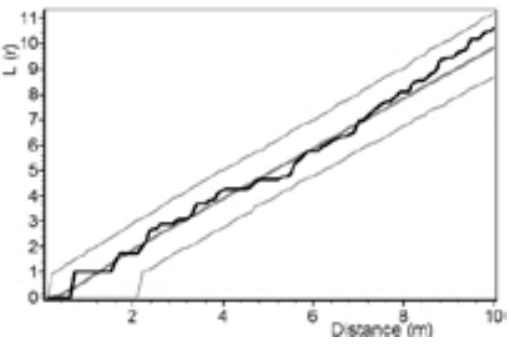

PRP 1 crown linden

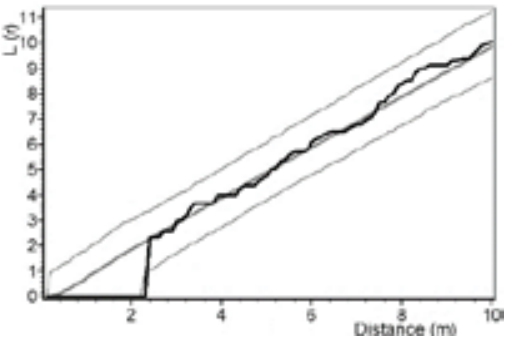

Fig. 4. Horizontal structure of tree stems and centres of crown projection areas of main tree species in high forest on permanent research plot 1 in 2014 expressed by $L$-function. 
PRP 2 tree stem oak

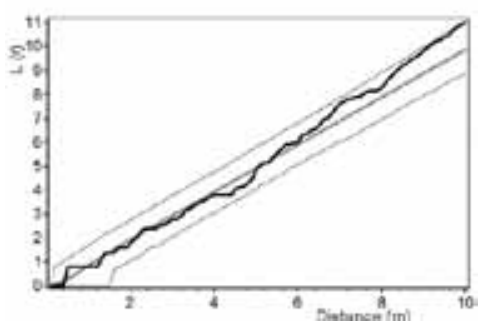

PRP 2 crown oak

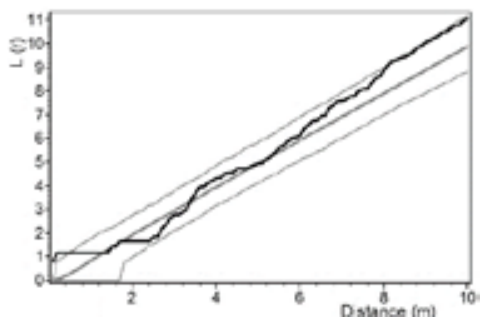

PRP 2 tree stem hornbeam

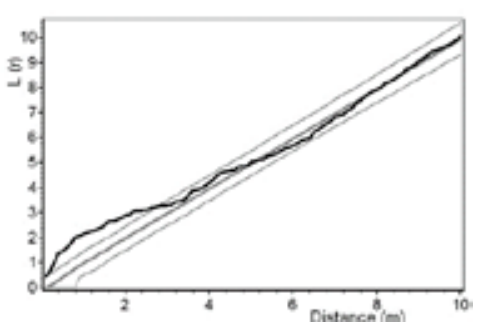

PRP 2 crown hornbeam

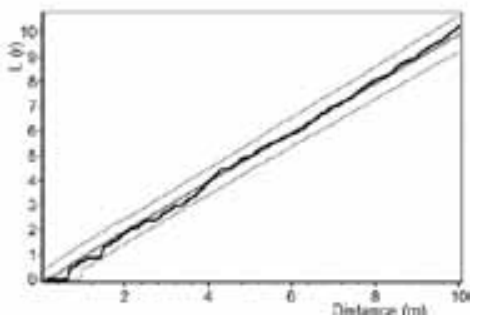

PRP 2 tree stem linden

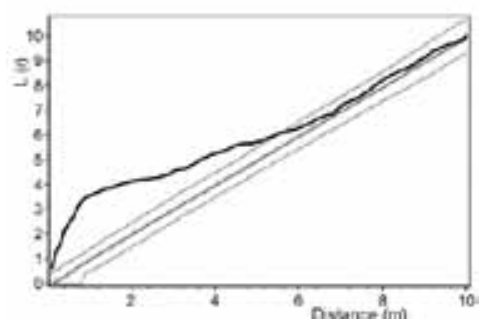

PRP 2 crown linden

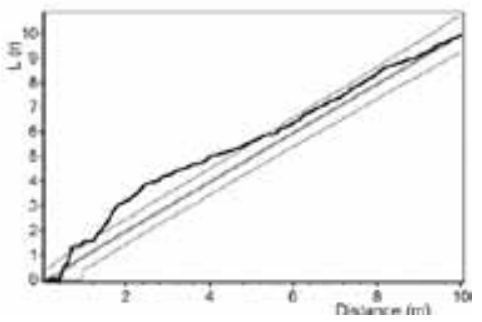

Fig. 5. Horizontal structure of tree stems and centres of crown projection areas of main tree species in coppice with standards on permanent research plot 2 in 2014 expressed by $L$-function.

PRP 3 tree stem oak

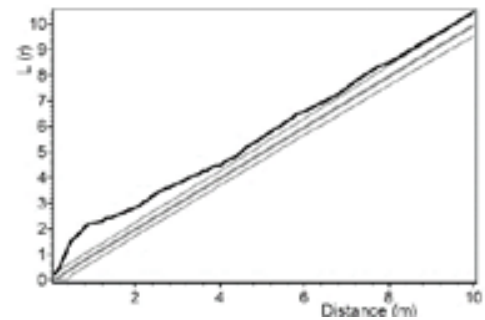

PRP 3 crown oak

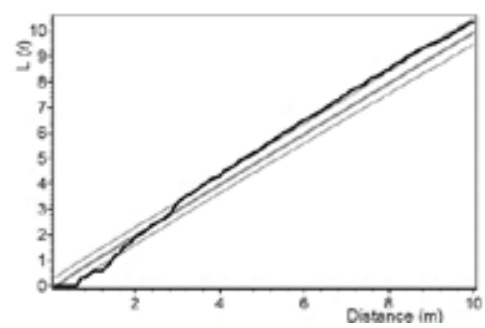

PRP 3 tree stem hornbeam

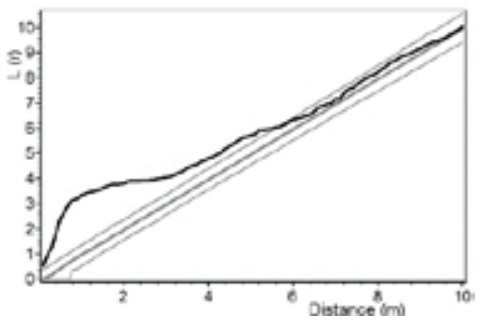

PRP 3 crown hornbeam

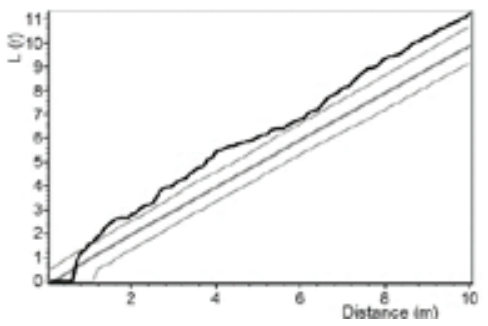

PRP 3 tree stem linden

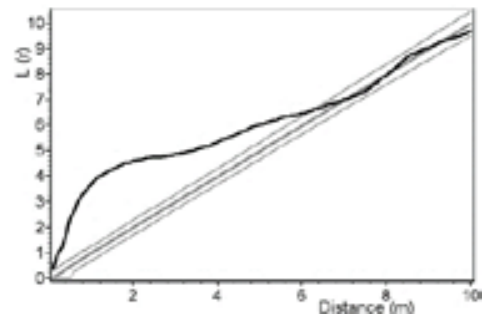

PRP 3 crown linden

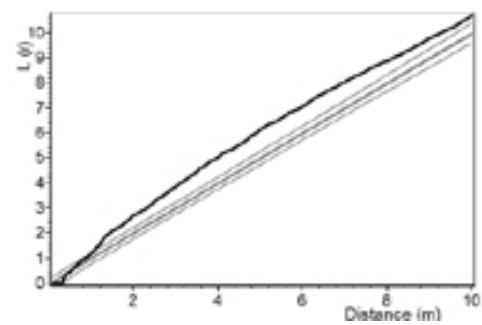

Fig. 6. Horizontal structure of tree stems and centres of crown projection areas of main tree species in low forest on permanent research plot 3 in 2014 expressed by $L$-function.

of trees shows a still larger shift towards regular structure (Table 4, Fig. 4 -6.). Horizontal structure of crown centroids in high forest on PRP 1 was regular according all study indices, while the stems of trees were randomly distributed according to $A, \alpha$ and $R$ indices. Similar situation occurred also in the low forest on PRP 3 and the coppice with standards on PRP 2, when the structure of the crown centroids was even regular according to $R$ index (aggregation in tree layer).
In high forest on PRP 1 the arrangement of the crown centres according to the $L$-function was more regular than that of the stem bases, especially at a distance of $1.5-4.5 \mathrm{~m}$ (Fig. 4). In hornbeam the distribution of tree crowns was regular at a distance of $2-4.5 \mathrm{~m}$ while in the other cases their distribution was random similarly like in the stem bases. In linden the centres of crown projection areas were distributed randomly similarly like the stem bases. In coppice with standards on PRP 2 the 
Table 4. Structural indices of centres of crown projection areas for the main tree species and all tree individuals on permanent research plot 1 (high forest), 2 (coppice with standards) and 3 (low forest) in 2014.

\begin{tabular}{|c|c|c|c|c|c|c|c|c|c|c|c|c|c|}
\hline \multirow{2}{*}{ Index } & \multirow{2}{*}{ Year } & \multicolumn{4}{|c|}{ PRP1 } & \multicolumn{4}{|c|}{ PRP 2} & \multicolumn{4}{|c|}{ PRP 3 } \\
\hline & & oak & hornbeam & linden & tree layer & oak & hornbeam & linden & tree layer & oak & hornbeam & linden & tree layer \\
\hline A & 2014 & $0.34^{\mathrm{R}}$ & $0.33^{\mathrm{R}}$ & $0.67^{\mathrm{A}}$ & $0.37^{\mathrm{R}}$ & 0.58 & 0.54 & $0.68^{\mathrm{A}}$ & 0.51 & 0.53 & $0.75^{\mathrm{A}}$ & $0.78^{\mathrm{A}}$ & 0.54 \\
\hline$\alpha$ & 2014 & $0.81^{\mathrm{R}}$ & $0.78^{\mathrm{R}}$ & $2.08^{\mathrm{A}}$ & $0.83^{\mathrm{R}}$ & 1.46 & 1.11 & 1.42 & 1.01 & 1.26 & $2.20^{\mathrm{A}}$ & $2.33^{\mathrm{A}}$ & 1.13 \\
\hline $\mathrm{R}$ & 2014 & $1.34^{\mathrm{R}}$ & $1.32^{\mathrm{R}}$ & 1.05 & $1.23^{\mathrm{R}}$ & 1.06 & 1.01 & $0.74^{\mathrm{A}}$ & $1.21^{\mathrm{R}}$ & 1.09 & $0.77^{\mathrm{A}}$ & $0.79^{\mathrm{A}}$ & 1.11 \\
\hline ICS & 2014 & $-0.45^{\mathrm{R}}$ & $-0.42^{\mathrm{R}}$ & 0.03 & $-0.56^{\mathrm{R}}$ & 0.09 & -0.18 & $0.54^{\mathrm{A}}$ & 0.02 & -0.02 & $0.45^{\mathrm{A}}$ & $0.78^{\mathrm{A}}$ & $0.36^{\mathrm{A}}$ \\
\hline
\end{tabular}

distribution of oak crown centres was random according to the $L$-function, rather tending towards regularity at a distance of about $2.5 \mathrm{~m}$ (Fig. 5). In hornbeam the crown centres were distributed randomly, also at spacing within $3 \mathrm{~m}$ when the distribution of stem bases was aggregated. Similarly, like the stem bases, the centres of linden crowns at a spacing of $1.5-4.5 \mathrm{~m}$ are also distributed in an aggregated manner, at the other distances randomly. In low forest on PRP 3 the distribution of the oak crown centres to a distance of $1.5 \mathrm{~m}$ was moderately regular, at a distance of $1.5-3 \mathrm{~m}$ it was random and at larger distances it was on the border of randomness and aggregation (Fig. 6). In hornbeam and linden, the centres of crown projection areas were distributed in a distinctly less aggregated manner than the stem bases, particularly at spacing within $4-5 \mathrm{~m}$. The crown centres at a distance above $6 \mathrm{~m}$ were an exception in linden that were arranged in an aggregated manner and the stem bases were distributed randomly.

The above described horizontal structure of the centres of crown projection areas of the study tree species was documented also by structural indices with some deviations (Table 4). On PRP 1 the tree distribution in most species (instead of linden) was regular across the forest stand according to the majority of the indices. On PRP 2 the majority of the indices show the random distribution of the centres of crown projection areas of trees in most tree species across the forest stand. Only in linden the distribution was aggregated. On PRP 3 the crown centres were distributed in aggregated manner almost in hornbeam and linden according to the studied indices. Oak was an exception in which the distribution of the crown centres was random.

Table 5 shows the values of distances of the crown projection area centres from the stem base on PRP according to the main woody species in 2014. The largest deviations of the crown centre from stem bases were determined in low forest where the average deviation of all tree species was $2.0 \mathrm{~m}$, followed by coppice with standards $-1.2 \mathrm{~m}$, and the smallest deviation was found out in high forest $-1.0 \mathrm{~m}$. The differences were statistically significant $(\mathrm{P}<0.01)$ only between low forest and coppice with standards on the one hand and high forest on the other.

Generally, higher degree of aggregation (higher for stems than crowns) was documented in low forest. The same trend was shown in coppice with standards in the case of linden and hornbeam. Oppositely, random to regular distribution for both stems and crown was shown in the case of high forest.
Table 5. The values of distances of the crown projection centres from the stem base for the main tree species and all tree individuals on permanent research plot 1 (high forest), 2 (coppice with standards) and 3 (low forest) and in 2014.

\begin{tabular}{lllccc}
\hline PRP & \multirow{2}{*}{ Forest form } & \multicolumn{1}{c}{ Species } & \multicolumn{3}{c}{ Distance [m] } \\
average & minimum & maximal \\
\hline \multirow{4}{*}{1} & \multirow{3}{*}{ High forest } & Oak & $1.0^{\mathrm{a}}$ & 0.0 & 5.0 \\
& & Hornbeam & $1.1^{\mathrm{a}}$ & 0.1 & 4.9 \\
& & Linden & $1.0^{\mathrm{a}}$ & 0.0 & 2.7 \\
& & Tree layer & $1.0^{\mathrm{A}}$ & 0.0 & 5.0 \\
\hline \multirow{4}{*}{2} & Coppice with standards & $1.1^{\mathrm{a}}$ & 0.1 & 3.8 \\
& & Hornbeam & $1.2^{\mathrm{a}}$ & 0.2 & 4.7 \\
& & Linden & $1.4^{\mathrm{a}}$ & 0.1 & 4.8 \\
& & Tree layer & $1.2^{\mathrm{A}}$ & 0.1 & 4.8 \\
\hline \multirow{3}{*}{3} & \multirow{3}{*}{ Low forest } & Oak & $2.0^{\mathrm{ab}}$ & 0.2 & 4.9 \\
& & Hornbeam & $1.6^{\mathrm{a}}$ & 0.1 & 4.1 \\
& & Linden & $2.3^{\mathrm{b}}$ & 0.1 & 4.6 \\
& & Tree layer & $1.9^{\mathrm{B}}$ & 0.1 & 4.9 \\
\hline
\end{tabular}

Notes: significant differences $(\mathrm{P}<0.05)$ among tree species on each PRP separately are indicated by small different letters and among all tree layer on three PRP are indicated by capital different letters.

\subsection{Natural regeneration}

Vertical structure of recruits for particular PRP 1-3 is given in Fig. 7. The height distribution clearly shows the opposite situation with recruits density compared to diameter structure of tree layer that is also related to the particular types of forest (Fig. 2). The lowest number of recruits with poor vertical structure was observed in low forest, while high forest shows rich natural regeneration characterized by high height differentiation.

According to the computed indices on PRP in locality Doutnáč the horizontal structure of natural regeneration on all PRP was aggregated with tendency to randomness (Table 6). The highest aggregation was observed in high forest. The clumpy distribution of recruits according to their distance is also documented by the $L$-function (Fig. $8)$. In term of tree species, the horizontal structure of natural generative regeneration was mostly aggregated according to the $L$-function, only sporadically it was random at a spacing of 5-10 m. Prevailing aggregated distribution of recruits was also confirmed by structural indices. They document that the pattern of natural generative regeneration was random only exceptionally (Table 6).

Results of pair cross correlation analysis showed that relationship between spatial pattern of tree layer and natural regeneration was negative (regular) at smaller distance on PRP 1 and 2 (from stem base to 1.4 m; Fig. 9). In low forest spatial pattern of all natural regeneration individuals in relation to canopy trees was evaluated as aggregated (positive relationship). Spatial pattern at 
PRP 1

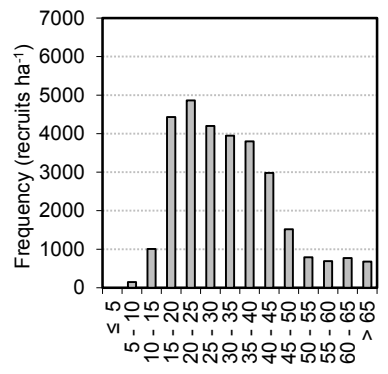

Height class $(\mathrm{cm})$
PRP 2

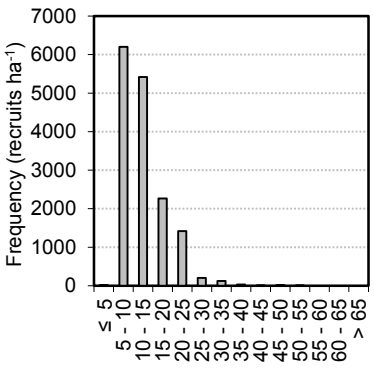

Height class $(\mathrm{cm})$
PRP 3

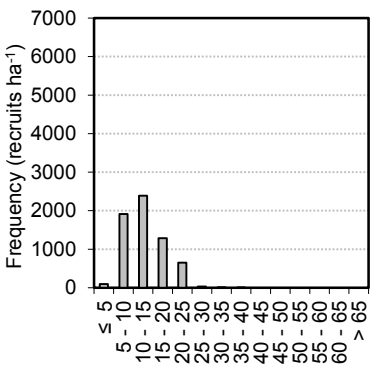

Height class $(\mathrm{cm})$

Fig. 7. Height structure of natural regeneration on permanent research plots 1 (high forest), 2 (coppice with standards) and 3 (low forest).

PRP 1

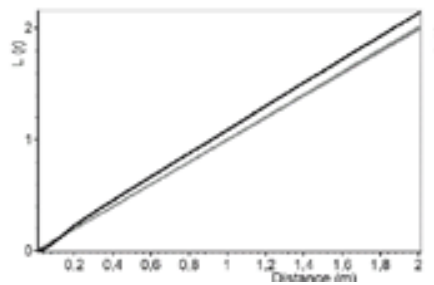

PRP 2

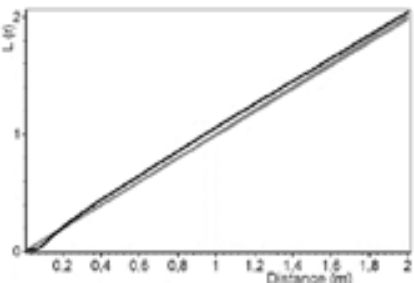

PRP 3

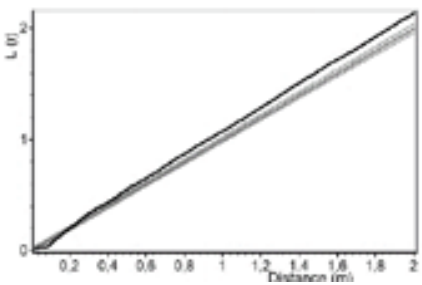

Fig. 8. Horizontal structure of natural regeneration on permanent research plots 1 (high forest), 2 (coppice with standards) and 3 (low forest) and expressed by $L$-function.

PRP1

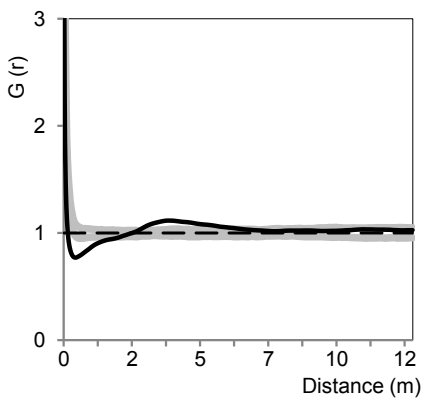

PRP 2

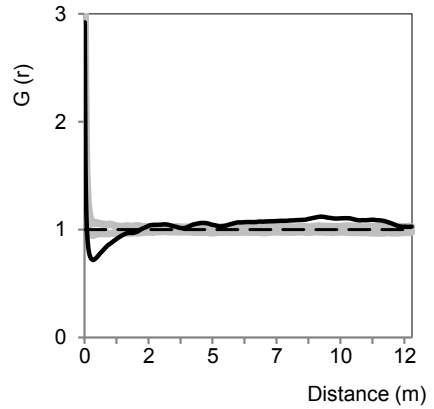

PRP 3

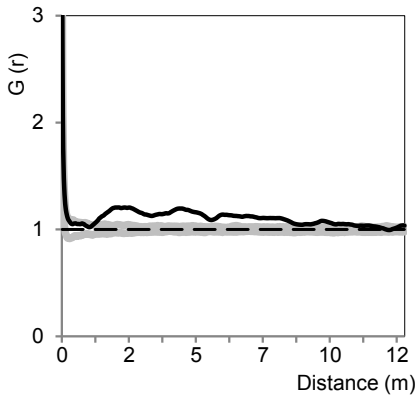

Fig. 9. Spatial relations of natural regeneration and the tree layer on the permanent research plots $1-3$ expressed by the pair correlation function; the black line depicts the pair correlation function $G(r)$ for real distances between individuals on the permanent research plots; two grey curves illustrate the $95 \%$ confidence interval for the random spatial pattern; $r$-radius defining distance between the selected points (trees and nature regeneration); $\mathrm{G}(r)>1$ indicates a clustering at distances $r$, while $G(r)<$ 1 indicates a regularity in the respective distances $r$.

Table 6. Structural indices of natural generative regeneration for the main tree species and all tree individuals on permanent research plot 1 (high forest), 2 (coppice with standards) and 3 (low forest) in 2014.

\begin{tabular}{|c|c|c|c|c|c|c|c|c|c|c|c|c|c|}
\hline \multirow{2}{*}{ Index } & \multirow{2}{*}{ Year } & \multicolumn{4}{|c|}{ PRP1 } & \multicolumn{4}{|c|}{ PRP 2} & \multicolumn{4}{|c|}{ PRP 3} \\
\hline & & oak & hornbeam & linden & regeneration & oak & hornbeam & linden & regeneration & oak & hornbeam & linden & regeneration \\
\hline A & 2014 & $0.61^{\mathrm{A}}$ & $0.71^{\mathrm{A}}$ & $0.86^{\mathrm{A}}$ & $0.60^{\mathrm{A}}$ & 0.63 & $0.71^{\mathrm{A}}$ & $0.66^{\mathrm{A}}$ & 0.52 & 0.59 & $0.90^{\mathrm{A}}$ & 0.42 & $0.55^{\mathrm{A}}$ \\
\hline$\alpha$ & 2014 & $1.60^{\mathrm{A}}$ & $3.21^{\mathrm{A}}$ & 1.96 & $1.58^{\mathrm{A}}$ & $2.13^{\mathrm{A}}$ & $3.81^{\mathrm{A}}$ & $2.11^{\mathrm{A}}$ & 1.09 & 1.35 & $4.55^{\mathrm{A}}$ & 1.01 & $1.23^{\mathrm{A}}$ \\
\hline $\mathrm{R}$ & 2014 & 1.03 & 0.88 & $0.44^{\mathrm{A}}$ & $0.92^{\mathrm{A}}$ & 0.92 & 0.92 & 0.99 & $0.95^{\mathrm{A}}$ & 0.95 & $0.70^{\mathrm{A}}$ & 1.15 & 1.02 \\
\hline ICS & 2014 & $0.71^{\mathrm{A}}$ & 0.05 & $0.24^{\mathrm{A}}$ & $0.22^{\mathrm{A}}$ & $0.22^{\mathrm{A}}$ & 0.12 & $0.15^{\mathrm{A}}$ & $0.14^{\mathrm{A}}$ & 0.07 & 0.19 & 0.03 & $0.16^{\mathrm{A}}$ \\
\hline
\end{tabular}

Notes: ${ }^{\mathrm{A}, \mathrm{R}}$ statistically significant $(\alpha=0.05 ; \mathrm{A}$ - aggregation, $\mathrm{R}$ - regularity). 
higher distances across the all plots was mostly random (no relationship).

\subsection{Interactions of stand characteristics and horizontal structure}

Results of the PCA analysis are presented in the form of an ordination diagram in Fig. 10. The first ordination axis explains $50.0 \%$ of the variability of data, the first two axes explain together $78.1 \%$ and the first four axes explain together $93.1 \%$ of the variability of data. The first $\mathrm{x}$-axis represents horizontal structure of tree layer and crown centroids. The second y-axis represents production parameters, resp. canopy (crown projection area), stand volume, mean height and DBH. Canopy and number of trees were positively correlated with one another, while these parameters were negatively correlated with $\mathrm{DBH}$ and height of trees. Distance of the crown projection centres from the stem base was positively correlated with $A$ and $\alpha$ aggregation indices (negatively with $R$ index). This crown to stem distance increased with increasing aggregation of the stand. Moreover, aggregation indices of crown centroids were regularly distributed than tree stems. In terms of tree species, linden showed the greatest crown plasticity and tendency to aggregate structure, instead, the distribution of oak directed to regularity. The forest management had the greatest effect on the spatial pattern compared to tree species and stand parameters. Horizontal structure of the high forest directed to regularity, while the distribution of the low forest was highly aggregated.

\section{Discussion}

Our results confirmed, that the spatial pattern is an important aspect of the stand structure with regard to forest management (Bílek et al. 2011; Li et al. 2014; Slanař et al. 2017). Moreover it determines a microclimate in the forest stand, circulation of gaseous substances released and taken up by trees and other plants in the forest stand, stem shape and the mutual interactions with neighbouring trees (Mizunaga \& Umeki 2001). Spatial pattern of forest stands influences many crucial ecosystem processes (Song et al. 2004; Pretzsch 2009) and horizontal structure plays a crucial role in interactions between the particular species and layers in plant communities (Dieckmann et al. 2000; Ngo Bieng et al. 2013), which also results from our study. These interactions participate in influencing the particular ecological processes such as growth, regeneration or mortality (Begon et al. 2006).

Relatively heterogeneous pattern was revealed on the studied plots according to structural indices: random representation prevailed in high forest and in coppice with standards, in low forest aggregated structure prevailed especially at a smaller spacing. These results are consistent with Jancke et al. (2009), who presented mostly aggregated distribution for low forests and random distribution for high forests. Results suggesting the random distribution of trees were also reported by Hui et al. (2007) or Li et al. (2012). Finally, the spatial pattern is strongly affected by site conditions (Vacek et al. 2015; Králíček et al. 2017). Structure influences the formation of the stand mosaic pattern in relation to the availability of light (Lhotka \& Loewenstein 2008), water and nutrients

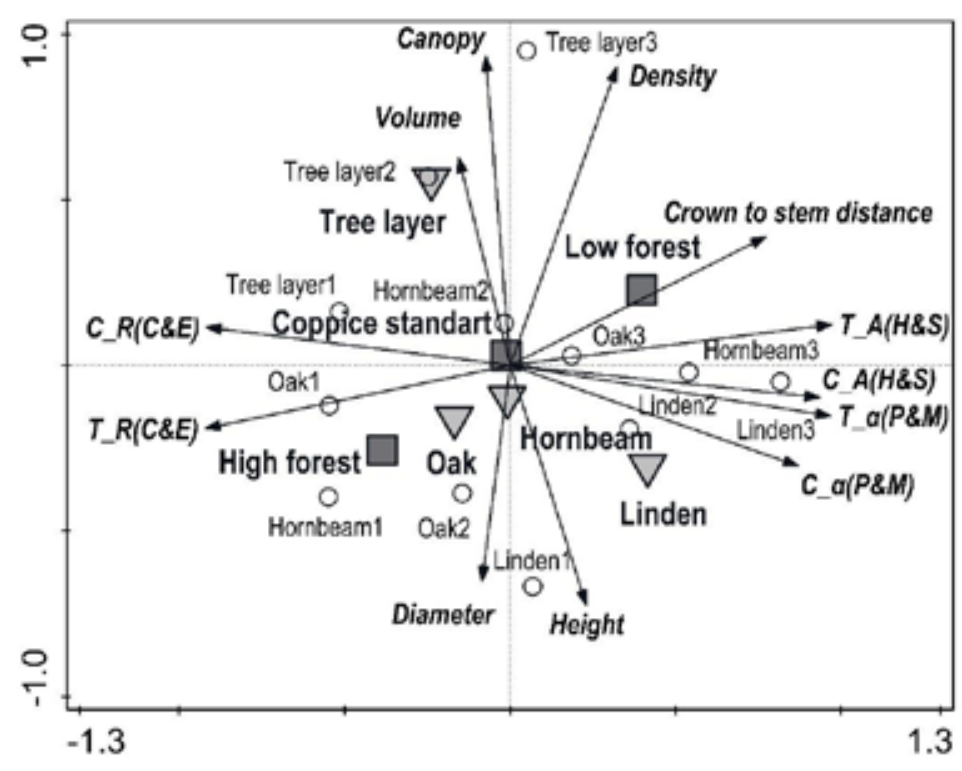

Fig. 10. Ordination diagram showing results of the PCA analysis of relationships between stand characteristics (Density number of live trees, Diameter mean quadratic diameter at breast height, Height mean height, Volume, Canopy crown projection area), and horizontal indices of tree layer (T) and Crowns (C) $[A(H \& S)$ Hopkins-Skellam index, $R(C \& E)$ Clark-Evans index, $\alpha$ (P\&M) Pielou-Mountford index]. Code abbreviation: - forest form (Low forest, Coppice with standards, High forest); $\boldsymbol{\nabla}$ tree species (Oak, Hornbeam, Linden, Tree layer), $\bullet$ tree species and number of plots $(1,2,3)$. 
within the entire forest ecosystem (Prescott 2002; Lang et al. 2012).

Our results are also consistent with results of Petritan et al. (2014), who reported random distribution for dominant trees in the forest stand, aggregated distribution at a distance of 8-12 $\mathrm{m}$ for middle storey and highly aggregated distribution for the lowest storey. The random spatial pattern of the tree layer is typical of the majority of high forest stands at the stage of optimum. Similar results were obtained in mixed forests in protected areas of middle Europe (Szwagrzyk \& Czerwczak M. 1993; Králičck et al. 2017; Vacek et al. 2016, 2017, 2018). Jancke et al. (2009) presented highly aggregated structure with two peaks for low forest when the one peak is at a distance of ca. $1 \mathrm{~m}$ and the other peak is at $5.6 \mathrm{~m}$ while the second peak is explained by the distance of stumps from which the low forest has sprouted. Aggregated structure was also reported by Getzin et al. (2008), who explained this structure on the basis of biotope heterogeneity; in our case this pattern of structure can be explained particularly by a different silvicultural system applied in the past. Similarly like in other studies of natural regeneration (Nagel et al. 2006; Ambrož et al. 2015), the spatial pattern of regeneration was aggregated. Aggregated structure for recruits can be further supported by limited (heavy) seed dispersal of some tree species (Getzin et al. 2008; Packham et al. 2012). Parent stand had significant effect on the spatial pattern of natural regeneration (Vacek et al. 2015b; Králíček et al. 2017). Negative interaction at smaller distances was observed in high forest and coppice with standards, but no relationship with tendency to aggregation was in low forest. Same situation because of vegetative regeneration was documented in Krkonoše Mountains (Bulušek et al. 2017). Microsite (Štícha et al. 2010; Vacek et al. 2015b), germination rate, seedling survival (Petritan et al. 2004), seed predation and dispersal by animals (Mosandl \& Kleinert 1998) are other factors that can influence spatial pattern of young trees.

With respect to the relatively short observation period (Kucbel et al. 2012) of 12 years, the results of our study show dynamics in the horizontal structure of the tree layer of studied tree species but more pronounced differences were revealed between stem and crown spatial pattern in the same period. Crown plasticity allows more effective utilization of growth space, which provides a potential to maintain the high productivity of forest (Schröter et al. 2012; Bulušek et al. 2017). In our study, distances between crown centroids and stem base ranged from $1.0 \mathrm{~m}$ in high forest to $2.0 \mathrm{~m}$ in low forest; the highest mean distance was observed in linden on PRP 3 (2.3 $\mathrm{m})$. For example within this range, displacement about $1.5 \mathrm{~m}$ was observed in beech forests in Czech Republic and Poland (Bulušek et al. 2017). Similarly, high crown plasticity was reported also by Olesen (2001) who documented also higher regularity of crown distribution compared to stems.
According to various research results (Li \& Li 2003; Kint 2005; Zhao et al. 2009) the present structure of studied forest stands will change, nevertheless changes in horizontal structure are rather slow. More pronounced changes can be expected in vertical and diameter structure with ongoing natural regeneration and its development. On the other hand, with abandonment of forest management, spontaneous development of stands will probably lead to a certain unification of stand structural characteristics in a broader scale.

\section{Conclusion}

The study significantly confirms the hypothesis about the influence of forest management on the spatial pattern of hornbeam-oak forests and their stand structural characteristics. Doutnáč locality in the NNR Karlštejn has a heterogeneous structure of tree layers and natural regeneration on the studied plots as result of different silvicultural systems applied in the past. However, slightly heterogeneous habitat (slope, exposure) and stand conditions (age) of the compared plots must be considered when interpreting the present results. Despite this, we see evident tendencies in stand development for particular management systems. Generally, higher degree of aggregation was documented in low forest. The same trend was shown in coppice with standards in the case of linden and hornbeam. In the case of high forest, random to regular distribution for both stems and crown was shown. Crown centroids of trees were more regularly distributed than tree stems, especially in linden. Oppositely small crown plasticity was observed in oak. Saplings and seedlings were mostly aggregated, but with increasing size of recruits their spatial distribution mainly in the case of high forest tends to be random.

\section{Acknowledgements}

The study was supported by the Ministry of Agriculture of the Czech Republic (Project No. QJ1530298) and by the Czech University of Life Sciences Prague, Faculty of Forestry and Wood Sciences (Project IGA No. B03/17).

\section{References}

Ambrož, R., Vacek, S., Vacek, Z., Král, J., Štefančík, I., 2015: Current and simulated structure, growth parameters and regeneration of beech forests with different game management in the Lány Game Enclosure. Lesnícky časopis - Forestry Journal, 61:78-88.

Begon, M., Townsend, C. R., Harper, J. L., 2006: Ecology: from individuals to ecosystems, $4^{\text {th }}$ edn. Oxford, Blackwell Publishing, 750 p.

Bílek, L., Remeš, J., Zahradník, D., 2011: Managed vs. unmanaged. Structure of beech forest stands (Fagus sylvatica L.) after 50 years of development, Central Bohemia. Forest Systems, 20:122-138. 
Bulušek, D., Vacek, Z., Vacek, S., Král, J., Bílek, L., Králíček, I., 2016: Spatial pattern of relict beech (Fagus sylvatica L.) forests in the Sudetes of the Czech Republic and Poland. Journal of Forest Science, 62:293-305.

Burrascano, S., Sabatini, F. M., Blasi, C., 2011: Testing indicators of sustainable forest management on understorey composition and diversity in southern Italy through variation partitioning. Plant Ecology, 212:829-841.

Clark, P.J., Evans, F. C., 1954: Distance to nearest neighbour as a measure of spatial relationship in populations. Ecology, 35:445-453.

Courbaud, B., Goreaud, F., Dreyfus, P., Bonnet, F. R., 2001: Evaluating thinning strategies using a tree distance dependent growth model: some examples based on the CAPSIS software "unevenaged spruce forests" module. Forest Ecology and Management, 145:15-28.

Cukor, J., Baláš, M., Kupka, I., Tužinský, M., 2017: The condition of forest stands on afforested agricultural land in the Orlické hory Mts. Journal of Forest Science, 63:1-8.

David, F. N., Moore, P. G., 1954: Notes on contagious distributions in plant populations. Annals of Botany of London, 18:47-53.

Dieckmann, U., Law, R., Metz, J. A. J., 2000: The geometry of ecological interactions: simplifying spatial complexity. Cambridge, Cambridge University Press, $516 \mathrm{p}$.

Fujimori, T., 2001: Ecological and Silvicultural Strategies for Sustainable Forest Management. Amsterdam, Elsevier, 398 p.

Fuller, R. J., 1992: Effects of coppice management on woodland breedings birds. In: Buckley G. P. (ed.): Ecology and Management of Coppice Woodlands. London, Chapman and Hall, p. 169-193.

Fürst, C., Vacik, H., Lorz, C., Makeschin, F., Podrázský, V., Janeček, V., 2007: Meeting the challenges of process-oriented forest management - editorial. Forest Ecology and Management, 248:1-5.

Getzin, S., Wiegand, T., Wiegand, K., He, F., 2008: Heterogeneity influences spatial patterns and demographics in forest stands. Journal of Ecology, 96:807-820.

Goreaud, F., 2000: Apports de l'analysede la structure spatiale en forêt tempérée à l'étude et la modélisation des peuplements complexes. Doctoral thesis. Nancy, ENGREF (AgroParisTech), 527 p.

Goreaud, F., Pelissier, R., 2003: Avoiding misinterpretation of biotic interactions with the intertype K-12function: population independence vs. random labelling hypotheses. Journal of Vegetation Science, 14:681-692.

Gurnell, J., Hicks, M., Whitebread, S., 1992: The effects of coppice management on small mammalpopulations. In: Buckley G. P. (ed.): Ecology and Management of Coppice Woodlands. London, Chapman and Hall, p. 213-233.
Harms, K. E., Wright, S. J., Calderon, O., Hernandez, A., Herre, E. A., 2000: Pervasive density-dependent recruitment enhances seedling diversity in a tropical forest. Nature, 404:493-495.

Hédl, R., Kopecký, M., Komárek, J., 2010: Half a century of succession in a temperate oakwood: from speciesrich community to mesic forest. Diversity and Distributions, 16:267-276.

Hopkins, B., Skellam, J. G., 1954: A new method for determining the type of distribution of plant individuals. Annals of Botany, 18:213-227.

Hui, G. Y., Gadow, K. V., Hu, Y. B., Xu, H., 2007: Structure-based forest management. Beijing, China Forestry Press, $200 \mathrm{p}$.

Jancke, O., Dorren, L. K. A., Berger, F., Fuhr, M., Köhl, M., 2009: Implications of coppice stand characteristics on the rockfall protection function. Forest Ecology and Management, 259:124-131.

Kint, V., 2005: Structural development in ageing temperate Scots pine stands. Forest Ecology and Management, 214:237-250.

Kopecký, M., Hédl, R., Szabó, P., 2013: Non-random extinctions dominate plant community changes in abandoned coppices. Journal of Applied Ecology, 50:79-87.

Králíček, I., Vacek, Z., Vacek, S., Remeš, J., Bulušek, D., Král, J. et al., 2017: Dynamics and structure of mountain autochthonous spruce-beech forests: impact of hilltop phenomenon, air pollutants and climate. Dendrobiology, 77:119-137.

Kucbel, S., Saniga, M., Jaloviar, P., Vencurik, J., 2012: Stand structure and temporal variability in oldgrowth beech-dominated forests of the northwestern Carpathians: A 40-years perspective. Forest Ecology and Management, 264:125-133.

Lang, A. C., Härdtle, W., Bruelheide, H., Kröber, W., Schröter, M., Wehrden von H., Oheimb von, G., 2012: Horizontal, but not vertical canopy structure is related to stand functional diversity in a subtropical slope forest. Ecological Research, 27:181-189.

Lhotka, J. M., Loewenstein, E. F., 2008: Influence of canopy structure on the survival and growth of underplanted seedlings. New Forests, 35:89-104.

Li, Y., Hui, G., Zhao, Z., Hu, Y., 2012: The bivariate distribution characteristics of spatial structure in natural Korean pine broad-leaved forest. Journal of Vegetation Science, 23:1180-1190.

Li, J., Li, J., 2003: Regeneration and restoration of broadleaved Korean pine forests in the Lesser Xing'an Mountains of Northern China. Acta Ecologica Sinica, 23:1268-1277.

Li, Y., Ye, S., Hui, G., Hu, Y., Zhao, Z., 2014: Spatial structure of timber harvested according to structurebased forest management. Forest Ecology and Management, 322:106-116. 
Mason, C. F., MacDonald, S. M., 2002: Responses of ground flora to coppice management in an English woodland - a study using permanent quadrats. Biodiversity \& Conservation, 11:1773-1789.

Matthews, J. D., 1991: Silvicultural Systems. Oxford, Oxford University Press, 284 p.

Matula, R., Svátek, M., Kůrová, J., Úradníček, L., Kadavý, J., Kneifl, M., 2012: The sprouting ability of the main tree species in Central European coppices: implications for coppice restoration. European Journal of Forest Research, 131:1501-1511.

Mizunaga, H., Umeki, T., 2001: The relationships between tree size and spatial distribution of foliagemass within crowns of Japanese cedars (Cryptomeria japonica) in young plantations. Forest Ecology and Management, 149:129-140.

Montes, F., Canellas, I., del Rio, M., Calama, R., Montero, G., 2004: The effects of thinning on the structural diversity of coppice forests. Annals of Forest Science, 61:771-779.

Mosandl, R., Kleinert, A., 1998: Development of oaks (Quercus petraea (Matt.) Liebl.) emerged from birddispersed seeds under old-growth pine (Pinus sylvestris L.) stands. Forest Ecology and Management, 106:35-44.

Moser, W. K., Jackson, S. M., Podrázský, V., Larsen, D. R., 2002: Examination of stand structure on quail plantations in the Red Hills region of Georgia and Florida managed by the Stoddard-Neel system: an example for forest managers. Forestry, 75:443-449.

Mountford, M. D., 1961: On E. C. Pielou's index of nonrandomness. Journal of Ecology, 49:271-275.

Müllerová, J., Hédl, R., Szabó, P., 2015: Coppice abandonment and its implications for species diversity in forest vegetation. Forest Ecology and Management, 343:88-100.

Nagel, T. A., Svoboda, M., Diaci, J., 2006: Regeneration patterns after intermediate wind disturbance in an oldgrowth Fagus-Abies forest in southeastern Slovenia. Forest Ecology and Management, 226:268-278.

Němeček, J., Macků, J., Vokoun, J., Vavř́iček, D., Novák, P., 2001:Taxonomický klasifikační systém půd České republiky. ČZU, Praha, 78 p.

Ngo Bieng, M. A., Perot, T., de Coligny, F., Goreaud, F., 2013: Spatial pattern of trees influences species productivity in a mature oak-pine mixed forest. European Journal of Forest Research, 132:841-850.

Olesen, T., 2001: Architecture of a cool-temperate rain forest canopy. Ecology, 82:2719-2730.

Packham, J. R., Thomas, P. A., Atkinson, M. D., Degen, T., 2012: Biological flora of the British Isles: Fagus sylvatica. Journal of Ecology, 100:1557-1608.

Paillet, Y., Bergès, L., Hjältén, J., Ódor, P., Avon, C., Bernhardt-Römermann, M. et al., 2010: Biodiversity differences between managed and unmanaged forests: meta-analysis of species richness in Europe. Conservation Biology, 24:101-112.
Perry, G. L. W., Miller, B. P., Enright, N. J., 2006: A comparison of methods for the statistical analysis of spatial point patterns in plant ecology. Plant Ecology, 187:59-82.

Peterken, G. F., 1993: Woodland Conservation and Management. London, Chapman and Hall, $314 \mathrm{p}$.

Petritan, A. M., Lüpke, B., von Petritan, I. C., 2007: Effects of shade on growth and mortality of maple (Acer pseudoplatanus), ash (Fraxinus excelsior) and beech (Fagus sylvatica) saplings. Forestry, 80:397412.

Petritan, I. C., Marzano, R., Petritan, A., Lingua, E., 2014: Overstory succession in a mixed Quercus petraea-Fagus sylvatica old growth forest revealed through the spatial pattern of competition and mortality. Forest Ecology and Management, 326:9-17.

Pielou, E. C., 1959: The use of point-to-plant distances in the study of the pattern of plant populations. Journal of Ecology, 47:607-613.

Pommerening, A., 2002: Approaches to quantifying forest structures. Forestry, 75:305-324.

Pommerening, A., Stoyan, D., 2006: Edge-correction needs in estimating indices of spatial forest structure. Canadian Journal of Forest Research, 36:1723-1739.

Prescott, C. E., 2002: The influence of the forest canopy on nutrient cycling. Tree Physiology, 22:1193-1200.

Pretzsch, H., Schütze, G., 2005: Crown allometry and growing space efficiency of Norway spruce (Picea abies L Karst.) and European beech (Fagus sylvatica L.) in pure and mixed stands. Plant Biology, 7:628639.

Pretzsch, H., 2009: Forest dynamics, growth, and yield. In Forest Dynamics, Growth and Yield, Springer Berlin Heidelberg, p. 1-3.

Ripley, B. D., 1981: Spatial statistics. New York, John Wiley \& Sons, 252 p.

Schröter, M., Härdtle, W., Oheimb von G., 2012: Crown plasticity and neighborhood interactions of European beech (Fagus sylvatica L.) in an old-growth forest. European Journal of Forest Research, 131:787-798.

Slanař, J., Vacek, Z., Vacek, S., Bulušek, D., Cukor, J., Štefančík, I. et al., 2017: Long-term transformation of submontane spruce-beech forests in the Jizerské hory Mts.: dynamics of natural regeneration. Central European Forestry Journal, 63:213-225.

Song, B., Chen, J., Silbernagel, J., 2004: Three-dimensional canopy structure of an old-growth Douglas-fir forest. Forest Science, 50:376-386.

Spitzer, L., Konvička, M., Beneš, J., Tropek, R., Tuf, I., Tufova, J., 2008: Does closure of traditionally managed open woodlands threaten epigeic invertebrates? Effects of coppicing and high deer densities. Biological Conservation, 141:827-837.

Stoyan, D., Stoyan, H., 1992: Fraktale Formen und Punktfelder: Methoden der Geometrie-Statistik. Berlin, Akademieverlag GmbH, 394 p. 
Sumida, A., Terazawa, I., Togashi, A., Komiyama, A., 2002: Spatial arrangement of branches in relation to slope and neighbourhood competition. Annals of Botany, 89:301-310.

Szabó, P., 2010: Driving forces of stability and change in woodland structure: a case-study from the Czech lowlands. Forest Ecology and Management, 259:650656.

Szwagrzyk, J., Czerwczak, M., 1993: Spatial patterns of trees in natural forests of East Central Europe. Journal of Vegetation Science, 4:469-476.

Šplíchalová, M., Adamec, Z., Kadavý, J., Kneifl, M., 2012: Probability model of sessile oak (Quercus petraea (Matt.) Liebl.) stump sprouting in the Czech Republic. European Journal of Forest Research, 131:1611-1618.

Štícha, V., Kupka, I., Zahradník, D., Vacek, S., 2010: Influence of micro-relief and weed competition on natural regeneration of mountain forests in the Šumava Mountains. Journal of Forest Science, 56:218-224.

Tolasz, R., Míková, T., Valeriánová, T., Voženílek, V. (eds.), 2007: Climate atlas of Czech. Czech Hydrometeorological Institute and Palacký University, Olomouc, $255 \mathrm{p}$.

Vacek, S., Lepš, J., 1996: Spatial dynamics of forest decline: the role of neighbouring trees. Journal of Vegetation Science, 7:789-798.

Vacek, S., Vacek, Z., Podrázský, V., Bílek, L., Bulušek, D., Štefančík, I. et al., 2014: Structural Diversity of Autochthonous Beech Forests in Broumovské Stěny National Nature Reserve, Czech Republic. Austrian Journal of Forest Science, 131:191-214.

Vacek, Z., Vacek, S., Bílek, L., Remeš, J., Štefančík, I., 2015a: Changes in horizontal structure of natural beech forests on an altitudinal gradient in the Sudetes. Dendrobiology, 73:33-45.
Vacek, Z., Vacek, S., Podrázský, V., Bílek, L., Štefančík, I., Moser, W. K. et al., 2015b: Effect of tree layer and microsite on the variability of natural regeneration in autoch thonous beech forests. Polish Journal of Ecology, 63:233-246.

Vacek, Z., Vacek, S., Podrázský, V., Král, J., Bulušek, D., Putalová, T. et al., 2016: Structural diversity and production of alder stands on former agricultural land at high altitudes. Dendrobiology 75:31-44.

Vacek, Z., Vacek, S., Bulušek, D., Podrázský, V., Remeš, J., Král, J., Putalová, T., 2017: Effect of fungal pathogens and climatic factors on production, biodiversity and health status of ash mountain forests. Dendrobiology, 77:161-175.

Vacek, S., Vacek, Z., Kalousková, I., Cukor, J., Bílek, L., Moser, W. K. et al., 2018: Sycamore maple (Acer pseudoplatanus L.) stands on former agricultural land in the Sudetes - evaluation of ecological value and production potential. Dedrobiology, 79:61-76.

Vacik, H., Zlatanov, T., Trajkov, P., Dekanic, S., Lexer, M. J., 2009: Role of coppice forests in maintaining forest biodiversity. Silva Balcanica, 10:35-45.

Vanhellemont, M., Baeten, L., Verheyen, K., 2014: Relating changes in understorey diversity to environmental drivers in an ancient forest in northern Belgium. Plant Ecology and Evolution, 147:22-32.

Ward, J. S., Parker, G. R., Ferrandino, F. J., 1996: Longterm spatial dynamics in an old-growth deciduous forest. Forest Ecology and Management, 83:189-202.

Zhao, Z., Hui, G., Yuan, S., Liu, W., Wang, R., 2009: Spatial structure characteristics of a Quercus aliena var. acuteserrata natural forest in Xiaolongshan. Scientia Silvae Sinicae, 45:1-6. 